\title{
DOMINIUM TERRAE? THE RISE OF THE WEST DURING THE AGE OF DISCOVERY AS A POSSIBLE ANALYTICAL PARADIGM IN HISTORY TEACHING IN GERMANY AND SPAIN
}

\author{
Dominium terrae? El auge de Occidente durante la Edad \\ de los Descubrimientos como un paradigma analítico en \\ la enseñanza de la Historia en Alemania y España
}

\author{
Maximilian Veigel \\ MaximilianVeigel@web.de \\ University of Augsburg. Germany \\ Diego Miguel-Revilla \\ dmigrev@sdcs.uva.es \\ University of Valladolid. Spain \\ Date of reception: $27 / 04 / 2021$ \\ Date accepted: 14/05/2021
}

\begin{abstract}
This article provides an in-depth analysis and discussion of the global-historical theory of the so-called Rise of the West during the Early Modern Age and the commonly named Age of Discovery. This theory is covered from the point of view of history education in order to question and provide a criticial examination of the framework. On the one hand, the controversial state of research of the topic is outlined, focusing on the main theoretical debates and some of the most noteworthy ideas under discussion. On the other hand, a discussion is also provided regarding some of the special requirements and essential conditions for an implementation of the idea of the Rise of the West in the curriculum. These notions are linked to both the traditional and current narratives that can be found in the German and Spanish national contexts. From this point of view, the politics of history of both nations are outlined, and, in addition, in order to provide some exemplifications, a selection of history textbooks from previous decades have been also examined in order to analyze the way some of the
\end{abstract}


narratives and these themes are presented. A series of categories, including historical myths, and the Rise of the West as a special category, as well as its institutional dimensions are also discussed in order to showcase the potential of the theory and some of the shortcomings that were detected from the perspective of history education.

Keywords: history education; textbooks; history teaching; rise of the West; historical narratives.

Resumen: Este artículo proporciona un análisis en profundidad y una discusión sobre la teoría histórico-global del Auge de Occidente durante el inicio de la Edad Moderna y la tradicionalmente llamada Edad de los Descubrimientos. Esta teoría se aborda desde el punto de vista de la educación histórica con el fin de cuestionar y proveer un examen crítico de este marco. Por un lado, el controvertido estado de la cuestión de este tema se detalla, focalizándose en los principales debates teóricos y algunas de las ideas en debate más destacadas. Por otro lado, se presenta una discusión sobre algunos de los requisitos especiales y las condiciones esenciales para la implementación de la idea del Auge de Occidente en el currículo. Estas nociones están vinculadas a las narrativas tradicionales y actuales que pueden encontrarse en los contextos nacionales alemán y español. Desde este punto de vista, las políticas de la Historia de los dos países son presentadas y, junto a ello, y con el objetivo de proveer de alguna ejemplificación, una selección de libros de texto de décadas anteriores ha sido examinada para analizar la forma en la que algunas de estas narrativas y temas se presentan. Una serie de categorías, incluídos los mitos históricos, el Auge de Occidente como una categoría especial, así como su dimensión institucional son también discutidas para presentar el potencial de la teoría y algunas de las limitaciones que fueron detectadas desde la perspectiva de la educación histórica.

Palabras clave: educación histórica; libros de texto; enseñanza de la historia; auge de Occidente; narrativas históricas.

CONTENTS: 1. The struggle for the conceptual and temporal framework of the Western Rise. 2.

Rise of the West? 3. "Europe» and "the West», an attempt at a working concept. 4. Politics of history as a precondition for history didactics. 5. German and Spanish politics of history. 6. Politics of history and the Rise of the West in the current history didactic discussion. 7. The historical myth as a tool for analysis. 8. The Rise of the West as a spatial category. 9. The Rise of the West and its institutional dimension. 10. The thematisation of the Rise of the West in the Early Modern Period in Spanish and German textbooks. 11. Final words: The Rise of the West as a framework. 12. References. 13. Textbooks that were consulted.

The potato age

And so the Fifth Empire experienced a period of peace and never before seen prosperity. And though it did not endure, it is well remembered as a happy moment in the history of the New World. [...] Atahualpa had undertaken further resettlements: The poor peasants from Swabia, Alsace and the Netherlands were settled in the most infertile areas of Spain, where he put them in charge of extensive irrigation projects. The peasants from Spain came to the cold German lands and grew potatoes and quinoa. 
These soon spread to all parts of the empire and far beyond. Chanca-colonies were established in Saxony; they were to keep an eye on the Protestant households that still existed around Wittenberg. The Inca regulated the exchange of goods according to the respective needs of the people: He had avocados and tomatoes shipped to the German lands and in return supplied the Spaniards with German and Flemish beer; the black brew from Castile in exchange for the yellow brew from Alsace. An agreement was reached with Portugal that Atahualpa would cede his territories in Brazil to it. In return, the empire undertook not to dispute his spice trade and not to obstruct the Indian route around the African peninsula. [...] Seville was the hub of the world, Lisbon flourished. The northern ports of Hamburg, Amsterdam, Antwerp grew and prospered with the fortunes of the Fuggers. The temples of the sun multiplied at the expense of local idolatries, but these were tolerated, for the Treaty of Seville assured their continued existence in Spain, the Peace of Wittenberg in the rest of the Empire (Binet, 2020, pp. 282-283).

The counterfactual scenario that the French author Laurent Binet creates here seems familiar, but at the same time, the reader is confused by the idea that the "submission of the world» (Reinhard, 2017) could have taken place diametrically across the Atlantic: Europe as the «fifth part of the empire» of a globally expanding Inca empire, which immediately forms the "New World» from the latter's perspective; the Inca Athaualpa, who causes a veritable massacre among the Spaniards in the Plaza de San Martín in Salamanca and takes Emperor Charles V into his power; Indians who establish settlements in Central Europe; sun temples that displace cathedrals.

Absurd? Binet makes this reversal of fortune possible by chance: Vikings reach South America and bring iron smelting and horse breeding with them. Centuries later, Christopher Columbus meets formidable Indians who have developed immunities to European pathogens through earlier contact with the Norsemen. The expedition fails: Columbus does not return to Europe. The technology of the remaining caravels and firearms form the missing piece of the puzzle to subjugate the "Oriental» Europeans. A look at the history books reveals that history took a different course. Europe appears here as the Prometheus of humanity, its achievements as a conflagration whose spark was struck within its cultural sphere. Ex occidente lux.

Pankaj Mishra, a well-known critic of "Eurocentric» perspectives, recognises in this the "worldwide triumph of Western modernity» (Mishra, 2018, p. 377), seeing its triumph built on a foundation of the bones of the colonised. Through its achievements in the form of the nation state and the capitalist market economy, it became first hegemonic, then universal. A process so total that even when the West is geopolitically submerged, it will still remain universal as a symbol of modernity. 


\section{THE STRUGGLE FOR THE CONCEPTUAL AND TEMPORAL FRAMEWORK OF THE WESTERN RISE}

However, the terms "Europe» and "the West», which are used here as a matter of course, are not as unambiguous as they may seem at first. Rather, we are in contested terrain here, both academically and in terms of politics of history. This is especially true of history didactics, which moves between these two poles like hardly any other discipline. The so-called Rise of the West poses a particular challenge. This discussion unites the struggle over the interpretation and ultimately the occupation of terms such as "Europe» and "the West» and the level of the juxtaposition of the "own» and the "foreign» within a coordinated system of space and time. The respective framing in the form of the Rise of the West testifies to a certain irreconcilability of positions: on the one hand, it is castigated as "Eurocentric» and an expression of a brutalised global racist order of a «decades of racist imperialism whose consequences still endure» (Mishra, 2017); on the other hand, the defence of historiographical traditions and the critique of a hypermoral «Tears of the White Man» (Bruckner, 1986).

At the beginning of the article, reference was made to the relativising view of textbooks, which promise reassurance through the supposed normative power of the facts. However, history textbooks are always subject to changes in academic knowledge and discourse as well as to changing historical-political preconditions. Part of this process of interpretation is always the decision of what is emphasised, what is neglected and -perhaps most decisively- what remains unaddressed.

The period under study forms a point of contention within the discussion on the Rise of the West itself. From a certain point in time in the course of the industrialisation of Europe and a European-influenced North America, not only the rise but also the dominance of the "West» was evident. This fact was summed up laconically by the British writer and politician Hilaire Belloc in 1898:

Whatever happens, we have got

The Maxim gun, and they have not.

For this reason, the focus of the present study will be on the early modern era around the so-called Age of Discovery. In other words, before the period of the industrial utilisation of the steam engine through fossil energy sources. The present article has set itself the task of, on the one hand, describing the current state of research in this field ${ }^{1}$. On the other hand, possible theoretical-paradigmatic category

1 The state of research presented is based primarily on German-language literature, and as a supplement to Spanish research. German sources and literature -if not available in English translation- have been translated by the authors. 
formations for the methodological bundling of this complex theory are to be discussed in order to make them usable for a respective didactics of history. A cursory analysis of selected German and Spanish textbooks focused on teaching at lower secondary level will be used to illustrate the statu quo with regard to the topic and then to discuss desiderata and the resulting potential. Both nations could serve as interesting case studies due to their history, especially during the $20^{\text {th }}$ and $21^{\text {st }}$ centuries, and it might be possible to detect contrasts and similarities by taking into account the way history is taught and presented over time, both in authoritarian and democratic regimes, in each of these countries.

\section{RISE OF THE WEST?}

Within the academic debate on the constitution and classification of the Rise of the West, considered the central question of world historiography (Conrad, 2013), the global historian Jürgen Osterhammel identifies four major camps: historians working with culturalist approach; representatives who attempt to transfer approaches of the so-called New Institutional Economics to macro historiography; environmental historians; and state-centred historians. From his lookout Osterhammel (2020) recognises a certain irreconcilability between the different approaches, but the main battle line runs between the culturalists, especially in their postcolonial form, and the other camps ${ }^{2}$. This irreconcilability is rooted in the basic presuppositions of one's own perspective. Especially in postcolonial approaches, previous foundations of historiography are subjected to a fundamental critique:

Modern history, both early and late, was made by Europeans, who 'built a world around Europe', as historians 'know', according to Braudel. That is indeed the 'knowledge' of the European historians who themselves 'invented' history and then put it to good use. There is not even an inkling of suspicion that it may have been the other way around, that maybe it was the world that made Europe (Gunder Frank, 1998, p. 3).

This criticism is legitimately countered by the objection that -especially from a global-historical perspective- monoperspective approaches are rarely purposeful and are always the result of a wide variety of factors (Conrad, 2013). Within the discipline, there is a strong focus on economic history, whereby two fundamentally

2 Osterhammel (2020, pp. 302-304) also recognises the central desideratum of the debate in this fault line of irreconcilability and uncompromising attitude: the holistic approach to the fundamental question of -temporary- global European superiority in the military and political spheres and their mutual economic conditions. 
divergent explanatory models collide ${ }^{3}$. These cluster around the central question of when the "European» "the West» assumed a hegemonic political and economic position globally, a phenomenon Kenneth Pommeranz subsumed as Great Divergence. In explaining or relativising this phenomenon, two schools can be considered essential: a "Weberian» School and a global history along the lines of the so-called California School. The former sees primarily "cultural and political institutions» as the cause of the emerging dominance of the "West». In it appears

the conviction that the [...] institutional differences between East and West have developed over a very long period of time, i.e. since the Middle Ages or since the turn of the modern era, and that consequently the level of prosperity has also diverged for centuries (Kramper, 2009, p. 12).

The latter recognises a central deficit of such a narrowed "Eurocentric» perspective: the insufficient empirical basis of comparisons with non-European regions. The California School argues that the Great Divergence only emerged from the middle of the $18^{\text {th }}$ century onwards and that it was

not necessarily only external, but nevertheless essentially contingent, indeed downright accidental factors [that] would have caused major differences in development between East and West within a relatively short period of time, without this having been foreseeable in any way before the turn of the 18th to the 19th century (Kramper, 2009, p. 15).

This view is supplemented by postcolonial perspectives that subject the idea of a European special path to a fundamental critique by focusing on the «mutual constitution of metropolis and colonies» (Conrad \& Randeria, 2013, p. 33) 4 . The main point of criticism here is the "quasi-natural juxtaposition» in the form of a dichotomy between the "West» and the "rest» -a phenomenon known as «Eurocentrism». Referring to Robert Young, «Eurocentrism» is understood

as the more or less explicit assumption [...] that the general historical development considered characteristic of Western Europe and Northern America constitutes a model

${ }^{3}$ At this point, reference should be made to the meta-study by the economic historian Peter Kramper (2009, pp. 10-11), who attempted not only to compare the different theoretical blueprints, but also to compare and deal with the academic positions based on them. Two limitations in particular should be noted, which Kramper names in the run-up to his analysis: a geographical dimension through the restriction to the world regions of China and Europe and a temporal dimension to the last 1.000 years.

${ }^{4}$ The objective of the entanglement propagated here is not the reversal of Eurocentrism, but the setting of a corrective in the form of a de-centring of the West. 
against which the histories and social formations of all societies can be measured and evaluated. The specificity and historical differences of non-Western societies are accordingly described in a "language of deficiency» and treated as deficits (Conrad \& Randeria, 2013, p. 35).

In addition to emphasising the construct character of the "West», two assumptions are considered constitutive of «Eurocentrism»: Westernisation in the form of capitalism, political-military power and culture and institutions as the goal of history, based on the notion of a sui generis European dominance. In this bitterly debated terrain, an analysis must always take two points into account: on the one hand, the handling of historical facts, and on the other, the relativisation of the criteria from which these facts are composed. With regard to dealing with historical factuality, Richard J. Evans' dictum will be the guiding principle:

It [the past] really happened, and we can actually, if we are very conscientious, careful and self-critical, find out how it happened and develop some tenable interpretations of the past (Evans, 1999, p. 243).

\section{3. "EUROPE» AND "THE WEST", AN ATTEMPT AT A WORKING CONCEPT}

But what is meant by «Europe» and the "West» in this context? ${ }^{5}$ The very question of what is to be understood conceptually by the "West» is the subject of intense debate ${ }^{6}$. It is fundamental to emphasise that the "West» is a construct that finds expression in the Meistererzählung of "Western civilisation». In this context, the British historian Norman Davies urges us to think about the historical-political implications:

Western civilization is essentially an amalgam of intellectual constructs which were designed to further the interests of their authors. It is the product of complex exercises in ideology, of countless identity trips, of sophisticated essays in cultural propaganda (Davies, 1997, p. 25).

However, in this deconstructivist reading, a paradigmatic historical concept could hardly exist without exposing itself to the accusation of arbitrariness (Morris,

${ }^{5}$ Even while acknowledging its construct character, a relative historical effectiveness as a concept is to be assumed here.

${ }^{6}$ The present study will use "Europe» and the "West" synonymously, since according to the traditional reading, "Europe" is considered to be the foundation of the culture of the "West " (including the former British colonies). Compare the tradition of Western Civilisation teaching in the Anglo-Saxon world. 
2012, p. 49). The «West» represents a «metaphor» for a relatively indeterminate historical or political variable (Weidner, 2018, p. 35), which «serves to describe a set of norms, behaviours and institutions» (Ferguson, 2018, p. 48). The historical, geographical starting point of the "West» is identified as the western foothills of Eurasia (Gourou, 1989). Through a progressive formation of tradition, specific identity components were associated with the "West»: "from the roots of the Christian world in Greece, Rome, and Judaism to modern phenomena such as the Enlightment, modernization, romanticism, nationalism, liberalism, imperialism, totalitarism» (Davies, 1997, p. 15). The conditio sin qua non of a Western-European self-understanding is, as the world historian Wolfgang Reinhard points out, its expansiveness: «For Europe did not grow out of a given, clearly delimited geographical, ethnic or political substrate, but emerged through contingent processes of expansion" (Reinhard, 2017, p. 17). Through its indeterminacy and expansiveness, the expansion of the "West» is also always a global history of entanglement:

[t] he European expansion [...] can indeed claim to have ultimately made man's many worlds into the one world in which we live today. Certainly, such a perspective is Eurocentric, but that cannot be avoided in this case because the thing itself is Eurocentric (Reinhard, 2008, p. 375).

\section{POLITICS OF HISTORY AS A PRECONDITION FOR HISTORY DIDACTICS}

Of all the historiographical sub-disciplines, history didactics is perhaps the most presuppositional, since it has to satisfy the most politically set framework conditions. The Rise of the West is therefore always subject to historical-political requirements, especially in a history didactic context. But what is meant by the catchword politics of history in this context? The term is formed along two factors: on the one hand, a relationship of tension to each other, and on the other hand, by its twosided nature:

Defined in political terms, historical politics means any use of history to influence contemporary debates and their political consequences. Defined in historical terms, the term alludes to the problematic context that overall judgements and images of history that go beyond individual slices of reality always concern public affairs, namely the self-assurance of the res publica. They thus inevitably carry political implications. In the first perspective, "history in politics» is selectively utilised, in the second perspective, "history as politics» is put up for current disposition in interpretations. History politics includes legitimising and delegitimising strategies. Historical-political accents can also play an important role in the professional historical-political discussion and radiate from there into the public sphere (Wolfrum, 1999, p. 30). 
Building on this, one can reduce politics of history to the formula that

it is a public and mass-media mediated process in which visible forces and counter-forces are at work and struggle for the hegemony of discourses and patterns of interpretation. This process also includes the flip side of memory, the fading out and forgetting (Wolfrum, 1999, p. 28).

It is thus to be understood primarily as "functional». Its implementation is not least the responsibility of history didactics. It creates a "historical consciousness» through "concrete strategies that change the view of the past, break it, strengthen it or push it away" (Wolfrum, 1999, p. 27). The concepts and images of history expressed here are thus subject to constant revision in line with the Zeitgeist of the time. The discipline exerts its influence through its choice of topics, but Wolfrum emphasises that «the creation of consensus by appealing to historical commonalities (...) [naturally] takes place in a pre-scientific space» (Wolfrum,. 1999, p. 27). Building on this theoretical basis, Harald Schmid (2009, pp. 72-74) considers five analysis parameters to be essential: forms and means, contents and "products», functions, actors and normative contexts.

\section{GERMAN AND SPANISH POLITICS OF HISTORY}

But how does the politics of history take shape as a normative framework in a German and Spanish ${ }^{7}$ context? After the cataclysm of the Second World War, a historical-political melange of reform and restoration emerged on the territory of the nascent Federal Republic of Germany, which found expression in the framework of education within history teaching. The Free State of Bavaria is exemple of this process. In terms of content, the emphasis shifted in favour of more recent history. In 1953, the Standing Conference of the Ministers of Education and Cultural Affairs -a federal body of the then West German federal states- issued guidelines for history lessons, which basically pursue the goal that pupils "gain their own view of the world and of humanity [...]» and "understand political events [...] as a conflict and changing balance of forces from all areas of life». At the end of this process, there should be the awareness that «man is aware of his freedom, his bonds and his limits» (Baumgärtner, 2007, p. 353).

However, it was not until the 1960s that a reappraisal of historical National Socialism began, which was, however, placed in an association with Soviet Communism in the form of the "Guidelines for the Treatment of Totalitarianism in the

7 In particular, the Federal State of Bavaria and the former German Democratic Republic were chosen to illustrate German conditions. 
Classroom» of 1962. West German educational policy can thus be understood primarily in terms of its turning away from a tradition with totalitarian connotations and the commitment to the primacy of historical-political teaching, which has been reinforced by a loss of significance of a canon shaped by humanism since the $1960 \mathrm{~s}$ (Baumgärtner, 2007, p. 559). The use of historiography as a «science of legitimation» is not the sole privilege of dictatorial regimes, but is based on the intention of a community to reproduce itself within its history teaching - under the respective ideological-political auspices. In the context of the GDR, Mary Fulbrook therefore quite rightly points out that

Historical research -like the presentation of its results- [...] always contains a creative element, a piece of imaginative reconstruction and representation. It cannot live without the interpretation of the past for the present. [...] Of course, this cannot be done in a theoretical vacuum: Even the concepts in which we hold the past, with their meanings and evaluations, are part of our contemporary social and political world (Fullbrook, 1998, pp. 419-420).

In this regard, there is equality of aims between the political systems. For a system such as the GDR, different levels of historical politics must be distinguished, which were subject to different degrees of politicisation: publicly perceived contexts were more charged than the academic establishment, which must nevertheless be considered strongly ideologised:

Historiography in the GDR had to take place within the framework of a single, officially state-sanctioned paradigm that was remarkably resistant to the intrusion of empirical evidence (Fullbrook, 1998, p. 424).

A finding whose validity can also be seen in the form of the textbook. In the GDR, these were published exclusively by the state-owned publishing house Volk und Wissen and were subject to strict state control (Knopke, 2011).

Spanish historical policy stands -in whatever respect- in the shadow of Franco's dictatorship. The Spanish Civil War (1936-1939) and the beginning of the dictatorship abruptly interrupted reform efforts that had been striven for even before the proclamation of the Second Republic in 1931. In this era dominated «an idealist and regulatory conception of the reality of the history of education» (Viñao, 2014, p. $833)$, which sketched a "reactionary ${ }^{8}$ perspective on the "Golden Age» of $16^{\text {th }}$ and

8 "Reactionary" in this context is understood according to Mark Lilla: „Reactionaries are not to be equated with conservatives. That is the first difference one must know. Reactionaries are just as radical in their own way as revolutionaries, and like them, historical myth-making has them firmly in its grip. The time-turning expectation of a new social order or a rejuvenated man characterises the revolutionaries, apocalyptic fears of the dawn of a new dark age the 
$17^{\text {th }}$ century imperial Spain. At the same time, the political interests and political orientation during the diverse phases of the dictatorship (which lasted until at least 1975), was used in order to shed a negative light on specific historical eras, critizising the secular and liberal tendencies that had been very influencial in Spain in the past, especially since the $19^{\text {th }}$ century.

At the same time, it is possible to detect different approaches depending on the decade, especially when addressing from an educational point of view topics such as the Republic, the Civil War or the regime that was established after 1939 (Valls, 2009). From the point of view of the politics of history, the regime understood the narrative surrounding the war from differing perspectives: one of victory at the beginning, but also one of apparent reconcilitation after that, aspects that were reflected not only in the media and the propaganda, but also in the way history and the past was addressed at schools and also in the textsbooks (Valls, Parra \& Fuertes, 2017). In this case, the public legitimation of the coup d'Etat was prominent, and research shows that even basic facts about the democratic period, such as the name of the leaders or the main events, were disregarded or not addressed from an educational standpoint until later on, in the 1970s (Álvarez Oses et al., 2000).

After the return to democracy, the focus was on a modernising historiography that was able to publicly address some of the topics and interpretations that were previously provided in a veiled manner, or that were simply not permitted (Viñao, 2014). In fact, some of the most prominent scholars had to work from the exile, and were able to publish during the 1960s and 1970s, but some of the interpretations challenging the public discourse were not introduced until much later. Despite all this, recent studies indicate that historical contents highlighted in the Spanish curriculum have not changed that much, and that many of the key elements included still focus on emphasizing the golden age of the nation (Moreno \& Alvén, 2020), while at the same time avoid addressing controversial issues or interpretations about the past (Sabido-Codina \& Albert Tarragona, 2020). For this reason, the representation of the past and the uses of history that were promoted during the dictatorship remained very influential from an educational standpoint, affecting the way history has been taught until recently (González Delgado, 2015), not only regarding the $20^{\text {th }}$ century, but also eras such as the Age of Discovery or the era of imperial Spain or the presence of historical myths, something that will be addressed later on.

reactionaries. [...] The creed of the reactionary is post hoc, propter hoc -everything that comes after is conditioned by the before. His story begins with a happy, well-ordered state in which people know their place and live together in harmony because they submit to tradition and their God. [...] The reactionary spirit is a shipwrecked spirit. Where others see the stream of time flowing as it always has, the reactionary thinks he can recognise the fragments of paradise that swim past him. He is a refugee from history. The revolutionary sees a bright future hidden from others, and this image inspires him. The reactionary thinks himself immune to modern lies, sees the past in all its glory, and an image inspires him too.« (Lilla, 2018, pp. 19-20). 


\section{POLITICS OF HISTORY AND THE RISE OF THE WEST IN THE CURRENT HISTORY DIDACTIC DISCUSSION}

In this context, a current research discussion on history didactics in the German-speaking world can be read under Eurocentric-critical and deconstructivist auspices, which treats "Europe» as a construct and thus as a problem area. A history didactic discussion of the Rise of the West intensifies these premises, since the "own», i.e. "European», is placed in a hierarchically superior order to the "foreign» and is thus essentialised:

Finally, the importance of transregional or global perspectives for history didactics also results from the fact that the given «we» narrative promotes an essentialist understanding of "our history" by creating the illusion that it can be understood by itself. For example, one can hardly find a textbook that, when presenting European expansion, discusses the question of why Europe in particular -and not another region of the world -took this development. It seems to suffice that pupils know that Europe has gone this way. In doing so, one accepts that they may unconsciously interpret this development as an expression not only of the "European nature», but perhaps also of European superiority. For it is a characteristic effect of the national-historical container model that it implicitly suggests assumptions of singularity and also superiority, which are often taken far too much for granted to be critically examined (Popp, 2018, p. 18).

The treatment of the Rise of the West -especially in textbook presentationseems to be a desideratum. However, the underlying components are not. Dealing with the phenomenon of "Europe» is a field of work that affects different areas of work: What is understood by "Europe» and what does it include geopolitically and culturally? (Von Borries, 2007). This is a problem that is further exacerbated by its condensation into a «European identity». Influences and interactions with regard to the constitution of a "European» historical culture and historical consciousness are examined from a Eurocentric-critical point of view, which is why a research focus is placed on the area of history and identity formation, dedicated to the historical genesis of so-called othering (Von Borries, 2008), whose essence Carl Schmitt condensed in his famous dictum: "Tell me who your enemy is, and I will tell you who you are».

Schmitt's credo illustrates this core of essence, which is subjected to an elementary critical evaluation on the part of research. At the centre of this is the examination of the phenomenon of «identity» as an expression of individual and collective memory, which is manifested in the form of the "construction of histories, biographies and identities» and is subject to a constant and dynamic process of "reconstruction, reconstruction and sometimes misconstruction» (Von Borries, 2008, p. 119). As a result, «identity» tends towards a narrative structure. Research ascribes to national historiography a hinge function between "Europe» and «identity». Its preferred form is the European master narrative, in which the "own 
identity» is formed. A frequently occurring pattern is identified here: pan-European historical events are transformed into nation-state narratives, which then find their way into curricula and schoolbooks (Popp, 2007). Since the "own» can only take on its shape through the "existentially foreign», the construction of the "non-European» takes on a central role in this kind of master narrative, which is why it seems at least worthy of discussion from the perspective of history didactics (Popp, 2007, pp. 212-214). In this context, the development of a necessary theoretical toolkit for the analysis and evaluation of motives and goals of such constructions is called for. The challenge here is to capture a dual basic perspective on this very "Europe», which is expressed both emotionally and factually. This complexity makes a multidisciplinary approach inevitable (Huber, 2018). Furthermore, three central fields of work can be summarised in the outlook on the research field: The breaking up of a narrow national perspective on the topic, the identification of the construct character of a «European» history and, building on this, the deconstruction of these narratives (Schreiber, 2007). However, a blind spot in the research discussion can be identified, which is expressed in the opening quote of this article as «essentialist understanding». By ignoring this, an essentialist fallacy could arise that would suggest assumptions of singularity and superiority, respectively, growing out of a supposed «European being». There is a danger here of implicitly recognising a phenomenon, but ignoring the context that produced it: the "European being» made manifest through its institutions. In the end, doesn't a relativisation of an endogenously justified Rise of the West itself represent a «historical myth»?

\section{THE HISTORICAL MYTH AS A TOOL FOR ANALYSIS}

Due to its definitional fragmentation, which is not least due to the different discipline-specific approaches, a satisfactory meta-definition is basically unfeasible. This also applies to the historical myth ${ }^{9}$. Bernhard et al. (2019) emphasise the function of the historical myth, that "[t]he particular speciality of historical myths is the creation of narrative cohesion within a specific community and the reconnection of the present to a past that infuses it with meaning» (p. 13). Building on this and aiming at "developing learners' capacity to de-construct history» (Bernhard et al., 2019, p. 21), which should critically question historical narratives for their historical-mythical character (this raises the question of the factuality or fictionality of these historical narratives), the authors propose two defining axioms regarding the identification of the historical myth: 1 . on the basis of the plausibility of the

${ }^{9}$ With regard to a development as a theory for the study of history, or for the didactics of history, reference is primarily made to the contribution by Roland Bernhard, Susanne Grindel, Felix Hinz and Johannes Meyer-Hamme (2019). 
historical narratives and, 2. on the basis of the functions of these narratives in the historical consciousness of society. To put it more precisely, a "historical myth» is thus understood as:

1. A historical narrative familiar to the society in which it circulates, whose 'truth' is more or less acknowledged, yet whose plausibility, on closer inspection, appears problematic.

2. We find ourselves dealing with a myth when the political or aesthetic dimension dominates, or instrumentalises, the cognitive dimension of historical memory to such an extent that the story as narrated fails an examination of its plausibility, its Triftigkeit (Bernhard et al., 2019, pp. 20 \& 25).

The first axiom builds on Jörn Rüsen's «cogency-criteria», which act as a gold standard for whether a historical narrative is to be considered «true». This standard is expressed in three dimensions: an empirical one (freedom from contradiction with regard to the sources), a normative one (value- and morality-related approvability) and an aesthetic dimension (coherence of the sense-making process between past and future). From this, the authors derive the following plausibility criteria ex negativo:

a. The assertions it brings forth are in evident contradiction to historical sources or are fictions generated to fill gaps where no sources are available; this withdraws the narrative's foundation. A lack of empirical plausibility impels us to label such a narrative as a myth;

b. The putative meaning offered by the myth does not make sense, or makes sense no longer. In this way, values and orientations recognised by a society may become myths when the meaning drawn from them, albeit generative of broad consensus in the past, now fails to attract that consensus because of shifts in the frameworks of that society's recognition of legitimate meaning. Thus denied its power to create consensus, the narrative loses its normative plausibility and becomes a historical myth;

c. Retrospective attachments of meaning to past events lead to their evaluation in terms which we might, for example, deem an over-inflation of their importance; the consequence is uncertain narrative plausibility and therefore the narrative's classification as a historical myth (Bernhard et al., 2019, p. 22).

\section{THE RISE OF THE WEST AS A SPATIAL CATEGORY}

More exactly, the Rise of the West represents the territorial and institutional expansion of a space identified as the "West». As explained above, both the terms and the categorisations on which they are based are contested. The refer- 
ence to the indissolubility of space and time within space and time seems banal, so the setting of the synchronic parameter in the form of space seems more in need of explanation than the setting of the diachronic axis of time. Space as a category is more relatively constituted in its conceptual constitution (Rau, 2013). But express like a mantra emphasising its construct character, space only loses a little of its effectiveness, since it forms a central point of reference for human identity (Oswalt, 2019). As an analytical paradigm, the concept divides into two categorical conceptual understandings: absolute space and relational, or relative, space. As absolutum, it stands for a spatial concept that presupposes a homogeneous spatial frame of reference. In opposition to this is a relational, or relative understanding, which is defined "by a system of stock relations of simultaneously existing material objects» (Rau, 2013, p. 61). Whether absolute or relational/relative, space takes on a personal context of meaning through «a consistent structuring of spatial patterns of reference through their association with meaningful content» (Oswalt, 2019, p. 231):

The power of space is great, and it always has a creative and destructive effect at the same time. It is the basis of the desire of every human community for its own living space, for a place that grants it realisation, realisation and the possibility of life, and that gives it nourishment for body and life (Tillich, referenced in Günzel, 2013, p. 250).

This process takes place in the individual as well as in the surrounding collective. At the beginning of this process is the classification of space, as Émile Durkheim points out:

It [society] is only possible if the individuals and the things that compose them are divided into different groups, i.e. classified [...] This organisation of society naturally communicates itself to the space it occupies. In order to avoid any collision, each individual group needs a certain proportion of space. In other words, the total space must be divided, distinguished and aligned, and all people must be aware of this division and these alignments (Durkheim, referenced in Günzel, 2013, pp. 41-42).

Henri Lefebrve adds to and extends this with the thesis that in reality "social space comprises actions, the actions of both collective and individual subjects, [which] come into being and pass away, which accept and which act» (Rau, 2013, p. 48). A postcolonial fundamental critique strikes at this loophole when it points to the instrumentalised production of spaces. Edward Said exemplified this critique in the spatial dialectic between the "Orient» and the "West» that is ex negativo constituted from it, a dialectic that forms the backbone of the border: 
A group of people inhabiting a few hectares draw a border around their land and refer to the areas beyond as «the barbarian empire». This widespread practice of representing in the mind a familiar space as "ours» and the unfamiliar outside as "theirs» could be a completely arbitrary geographical demarcation. I speak of «arbitrary» here because the imaginary geography of the "our country/barbarian empire» variety does not even include the view of the barbarians themselves. Rather, it is enough that "we» set the boundaries: In doing so, we construct them as "them», their territory and mentality as different from «ours» (Said, referenced in Günzel, 2013, p. 263).

History didactics must face a certain ambivalence here, which manifests itself in the medium of the map: Space as a normative force of the factual on the one hand, and space as a relative construction on the other. It is a field in which the conditionality of space can be practised in terms of its multiperspectivity and controversiality. For the Rise of the West, the paradigm of a sectorally structured space lends itself to the consideration of various aspects of space. The linking of these different factual aspects and their narrative foundation takes the form of the historical master narrative, a context that Vadim Oswalt succinctly summarises: «In these spatial narratives, for example, spatial entities of the most diverse sizes (cities, empires, states, supranational organisations, civilisations) become protagonists» (Oswalt, 2019, p. 242). In the present case, this role is played by the West.

\section{THE RISE OF THE WEST AND ITS INSTITUTIONAL DIMENSION}

Making the institution usable as an analytical concept of work is a challenge in that the preliminary decision of the concepts used in the course of «the use of the concepts itself already contains preliminary decisions of perspective, by which the interpretations of social developments are co-determined", in the words of Rehberg (1994, p. 52). This author, revising an absolute «institutionalist» approach of his academic teacher Arnold Gehlen ${ }^{10}$, proposes the following definition:

${ }^{10}$ Rehberg considers Gehlen's theory of institutions to be fundamental (a viewpoint that is widely accepted in research (Thies, 2007, p. 115). However, Rehberg recognises in Gehlen an absolutism of the institution in its manifestation as a hierarchical order (Rehberg, 1994, p. 47). As a corrective, Rehberg reverses the initial perspective, which he calls the "perspective of concern»: «If one not only [emphasis by Veigel] starts from the relief [emphasis by the author] provided by the institutions, but puts these in relation to the institutionally generated burdens [emphasis by the author], only then does the possibility of a critical analysis of concrete institutions arise - and not only their apologetics» (Rehberg, 1994, p. 56). Although «institutions» thus still represent a normative force of the factual, in the sense of Émile Durkheim's fundamental interpretation as a "social fact» (Rehberg, 1994, p. 56), neither they nor their constituent elements represent an absolute that can escape a critical perspective. A fact that is relevant precisely because of Eurocentric constrictions in its construction. 
Ideally, «institutions» are those "social regulations» in which the principles and claims to validity of an order are symbolically expressed. This form of stabilisation of orientations finds its - highly increasable - expression in the formulation of an institutional guiding idea (more precisely: a complex of such ideas [...] permeated by struggles) as well as associated symbolisation systems [...]. In this way, the assertion of the intrinsic value and the intrinsic dignity of an arrangement of order is increased and enforceable, also due to the suggestion of a "functionality" that is superior to all ad hoc usefulness, including historical probation and supra-individuality (Rehberg, 1994, p. 56).

Institutions are thus «mediating instances of cultural production of meaning, through which stylisations of values and norms are made binding» (Rehberg, 1994, p. 57). Rehberg assumes a "cultural shaping of every social structure» (p. 57). Its expression is the institution as a "coagulated spirit» (Max Weber). On the political level, this means «that those units of the overall political structure are to be understood to a special degree as "institutions» in which the creation and maintenance of the culturally formed self-image of a group and, in this sense, a synthesis of ideational and practical orientations. Niall Ferguson identified about six institutions for the European context that he identified as causal for European advancement: Competition, Science, Property Rights, Medicine, Consumer Society, and Work Ethic (Ferguson, 2018, p. 45). In them, the decisive strategic power resource is condensed and developed to its full potential: individual human creativity in terms of problemsolving strategies (Ferguson, 2018, p. 475).

\section{THE THEMATISATION OF THE RISE OF THE WEST IN THE EARLY MODERN PERIOD IN SPANISH AND GERMAN TEXTBOOKS}

Last of all, if we look at the past statu quo with regard to the treatment of the Rise of the West for the period of the early modern period under the respective historical-political circumstances in the form of the treatments in Spanish and German textbooks, the lack of this as a topic is hardly surprising after the previous explanations. Rather, it is interesting to see how the constituent elements, historical myth, space and institutions are presented and related to each other ${ }^{11}$.

In the context of Spanish history books, the category of space provides the thrust of Europe's expansive potential and thus formed the elementary causal background of the Spanish, and thus also European, rise. Especially under the Franco regime, space was the ideological projection surface of an ideology that was

${ }^{11}$ This is an exemplary stocktaking of the topic. It is intended as an impetus for in-depth qualitative and quantitative follow-up studies. 
subject to an essentialist, distinctive and antagonistic self-image. Due to the frontline situation with an existentially hostile islamic force in the Mediterranean and on Europe's eastern border, mercantile self-assertion demanded reaching out to the West ${ }^{12}$. Later history books also identified the desire to establish and dominate maritime trade routes after the fall of Constantinople in 1453 as a causal motive of global European expansion, which has been presented as a key motive on many occasions $^{13}$. Unique to the Francoist era, however, is the self-evident mythologisation of the Spanish role in the course of this expansion: according to this, other decisive factors were the power and radiance of the global mission of the Roman Catholic Gospel and a heroic manliness essential to the Spaniards ("el espiritu aventurero propio del momento historico») ${ }^{14}$. In Spanish school historiography, the innovations achieved primarily in the fields of navigation, cartography and nautical science represent a narrative continuum across time and systems. However, it is only in this context that later textbook editions highlight the role of capitalism, as the «época del capitalismo inical ${ }^{15}$. What also remains unifying is the location within the emerging early modern Spanish empire in the interplay with a progressive EuropeanWestern penetration of the world.

It is important to note that previous research had found that, in Spain, textbooks still tend to focus on this period nearly exclusively from the point of view of the key historical events that took place during the imperial era, while at the same time disregarding additional perspectives (Moreno \& Martínez-Llorca, 2020). This was found to be in line with the fact that textbooks still lack an emphasis on historical thinking competences (Gómez Carrasco, 2014; Sáiz Serrano, 2014), which might lead them to instead focus on factual elements, ignoring potential work of aspects such as historical perspective or historical agency, while at the same time adopting a mainly national approach (Gómez Carrasco \& Molina Puche, 2017).

From an institutional perspective, in the GDR -for reasons of historical policy- a focus was placed on the formation of early capitalism, which was identified as an essential factor in the early modern voyages of discovery ${ }^{16}$. The European seizures were understood both in their process and in their consequences as a colonial process, which manifested itself within the economic system and has been preserved until the present day. Global-historical perspectives took a back seat to other fo-

12 This is something that was, for instance reflected in the textbook Historia Universal y de España, published by SM in 1965 for the 4th degree of Bachillerato Elemental.

${ }^{13}$ See, for instance, the textbooks Ciencias Sociales 70 EGB, published by Anaya in 1974, Ciencias Sociales, Geografía e Historia 20 Ciclo, published by Anaya in 1999, and Historia 20 ESO, published by Santilla in 2016.

${ }^{14}$ See Historia Universal y de España, published by SM in 1965, p. 168.

15 See, for example, Bóveda Ciencias Sociales 70 EGB, published by Anaya in 1983.

${ }^{16}$ See textbook Geschichte. Lehrbuch für Klasse 7, published in 1976, p. $12 f$. 
cal points -above all an historical-materialistic interpretation of the Reformation ${ }^{17}$. With the removal of historical materialism, this finding can also be observed in West and all-German contexts up to recent times ${ }^{18}$.

In the early modern period, a global dimension still culminates in the treatment of the Spanish conquista and the Portuguese advance into the Asian maritime space. Within the category of space in relation to Western expansion, the point of departure, or rather the turning point, is located, analogously to the traditional Spanish narrative, in the fall of Constantinople to the Ottomans in 1453, which at the same time marked the end of the previous Oriental trade. Parallel to this, a linear narrative thread of space and institution is linked in the form of the humanist-influenced Renaissance, which leads the Occident out of its autumn of the Middle Ages into a new era.

This process, the spatial and the development of institutions (or their achievements, i.e. innovations) coagulate in a prototypical way in Columbus' voyage of exploration. In this context, the myth of Columbus and the narrative of the "white gods ${ }^{19}$ and their conquest of Meso and South America represent the most powerful historical myth that still persists ${ }^{20}$. Europe's subsequent claim to total dominion manifested itself in the so-called Treaty of Tordesillas in 1529 . There was a tendency for the subject complex to be placed in a colonial context, as a supplement to a contemporary idea of empire. Furthermore, interpretations can be discerned that embed these developments in an early globalisation process, for example through the teaching of the mutual intercontinental spread of respective farm animals and plants. The development of "early capitalism» and its instruments is emphasised as a fundamental catalyst of subsequent developments, but the perspective here remains mostly on the European context. The humanist renaissance, the search for alternative geographical areas of expansion and the corresponding scientific and technological innovation form the triad of Western ascent.

Older textbooks also display stronger evaluative tendencies in the form of the juxtaposition of "cultural differences», as well as a stronger historicisation within this evaluation (in some textbook publications also strongly mixed with a «question

${ }_{17}$ In later editions, this perspective is further strengthened. See, for example the textbook Geschichte 7. Lehrbuch für Klasse 7 published in 1989.

${ }^{18}$ However, recent editions of history textbooks and curricula have tended to re-emphasise global-historical themes and perspectives across the Länder.

${ }^{19}$ See the textbook bsv Geschichte 2. Vom frühen Mittelalter bis zum Westfälischen Frieden (bsv Geschichte in vier Bänden. Band 2 für die 8. Jahrgangsstufe der Gymnasien), published in 1983, p. 153 (2013).

${ }^{20}$ Here we would like to expressly refer to the standard work on this subject in Bernhard 
of guilt»)21. Current textbooks (such as Geschichte und Geschehen 7, published in 2019) attempt to take up the phenomenon through thematic longitudinal sections and spatial cross-sections (especially with Greater China) without explicitly naming it: spatial (the Atlantic as the "European sea» and the struggle with the Ottoman Empire in the Mediterranean), and institutional (the knowledge revolution of the Renaissance and its innovations brought about in the course of this) factors are worked out in a conditional manner. The treatment of globalisation is thematised as an earth-spanning network of Europeanisation. Other regions are recognised in their development and participation in this process, but always in the European context of a «Europeanisation of the Earth».

\section{FINAL WORDS: THE RISE OF THE WEST AS A FRAMEWORK}

After addressing previous debates and focusing on Germany and Spain in particular, it is possible to conclude that directing the attention to The Rise of the West as a topic of research could be of use, both from a theoretical and from a practical approach. In this sense, and while these two nations have been used as examples, it would be interesting to further explore the way this theme has influenced historiography and history education in other European nations, as well as to identify potential contrasts and similarities. In any case, in these specific cases, the impact of the particular ideosincracies of Germany and Spain, as well as their particular political structures, and how they have changed over time seem to have influenced debates, perceptions and representations. Future research lines might address some of these ideas and explore them further taking into account particular differences in each era.

The contents dealt with in this paper remain woodcut-like in terms of their depth and sharpness, but an elementary strength of the Rise of the West as a framework of analysis emerges: the bundling and ordering of different historical subject areas, as well as the critical reflection on the constitution of this framework of analysis and its preconditions preceding the academic space. At this point, the central point of criticism, in the form of a too high degree of complexity with regard to the age of the learners, can also be raised. However, it can be argued here that students can learn to recognise the reciprocal dialectics between the categories and space and institutions on the basis of one phenomenon and to transfer them structurally to other phenomena, especially with regard to the respective conditions of the rise and fall of specific large spaces.

Previous case studies in textbook presentations -whether in Germany or Spain- are often limited to very linear descriptions of symptoms and refrain from

${ }^{21}$ See, for example, the textbooks Fragen an die Geschichte 2. Die europäische Christenheit from 1993 and Fragen an die Geschichte 2. Die europäische Christenheit from 1979. 
contextualising underlying facts and conditions. It is precisely this knowledge of structural patterns that prevents an essentialist fallacy on the part of the learners, who assume too sweepingly a European exceptionalism. This is where the role of the historical myth comes into play, which also conveys to the learners that, firstly, every pattern of interpretation already carries a certain narrowing of perspective in its selection, and secondly, that this selection is shaped by political and social presuppositions in the form of a respective historical policy. These historical-political evaluations, for their part, are often characterised by a moral judgement of a respective epoch and its protagonists. In this context, Binet puts the following slogan into the mouth of Michel de Montaigne in his story, which can also serve as a memento for a positioning with regard to the Rise of the West: «[W]e are all descendants of victors and vanquished» (Binet 2020, p. 367).

\section{REFERENCES}

Álvarez Osés, J. A., Cal Freire, I., Haro Sabater, J., \& González Muñoz, M.a C. (2000). La guerra que aprendieron los españoles. República y guerra civil en los textos de bachillerato (1938-1983). Los libros de la Catarata.

Baumgärtner, U. (2007). Transformationen des Unterrichtsfaches Geschichte. Staatliche Geschichtspolitik und Geschichtsunterricht in Bayern im 20. Jahrhundert (Schriften zur Geschichtsdidaktik; Vol. 21). Schulz-Kirchner Verlag.

Bernhard, R. (2013) Geschichtsmythen über Hispanoamerika. Entdeckung, Eroberung und Kolonisierung in deutschen und österreichischen Schulbüchern des 21. Jahrhunderts. V\&R Unipress. https://doi.org/10.14220/9783737002042

Bernhard, R., Grindel, S., Hinz, F., \& Meyer-Hamme, J. (2019). Historical myth: a definition from the perspective of history education research. In R. Bernhard, S. Grindel, F. Hinz \& C. Kühberger (eds.). Myths in German-language Textbooks: Their Influence on Historical Accounts from the Battle of Marathon to the Élysée Treat (Eckert. Dossiers. Georg Eckert Institute for International Textbook Research; vol. 4) (pp. 12-34).

Binet, L. (2020). Eroberung [Civilisations]. Rowohlt.

Bruckner, P. (1986). The Tears of the White Man: Compassion as Contempt. The Free Press. 
Conrad, S. (2013). Globalgeschichte. Eine Einführung. Beck. https://doi. org/10.17104/9783406645747

Conrad, S. \& Randeria, S. (2013). Einleitung: Geteilte Geschichten - Europa in einer postkolonialen Welt. In S. Conrad et al. (ed.), Jenseits des Eurozentrismus. Postkoloniale Perspektiven in den Geschichts- und Kulturwissenschaften (2nd ed., pp. 32-72). Campus.

Davies, N. (1997). Europe. A History. Pimlico.

Evans, R. (1999). Fakten und Fiktionen. Über die Grundlagen historischer Erkenntnis [In Defence of History]. Campus.

Ferguson, N. (2018). Der Westen und der Rest der Welt. Die Geschichte vom Wettstreit der Kulturen [Civilization. The West and the Rest]. List.

Fulbrook, M. (1998). DDR-Geschichtswissenschaft und Geschichtspolitik. In G. G. Iggers et al. (ed.), Die DDR-Geschichtswissenschaft als Forschungsproblem (Historische Zeitschrift. Beihefte -Neue Folge-; Vol. 27), (pp. 419-429). De Gruyter Oldenbourg.

Gómez Carrasco, C. J. (2014). Pensamiento histórico y contenidos disciplinares en los libros de texto. Un análisis exploratorio de la Edad Moderna en 20 de la ESO. ENSAYOS, Revista de La Facultad de Educación de Albacete, 29(1), pp. 131-158. https://doi.org/10.18239/ensayos.v29i1.498

Gómez Carrasco, C. J., \& Molina Puche, S. (2017). Narrativas nacionales y pensamiento histórico en los libros de texto de Educación Secundaria de España y Francia. Análisis a partir del tratamiento de los contenidos de la Edad Moderna. Vínculos de Historia, 6(6), pp. 206-229. https://doi.org/10.18239/vdh.v0i6.276

González Delgado, M. (2015). «Tiempo de Turbulencias»: La compleja representación de la Guerra Civil española en los libros de texto de Ciencias Sociales (1970-1990). Espacio, Tiempo y Educación, 2(1), pp. 163-185. https:// doi.org/10.14516/ete.2015.002.001.009

Gourou, P. (1989). Geschichte und Geographie. In F. Braudel \& P. Gourou (ed.), Europa. Bausteine seiner Geschichte (pp. 99-121). Fischer.

Gunder Frank, A. (1998). ReOrient: Global economy in the Asian Age. University of California Press. https://doi.org/10.1525/9780520921313 
Günzel, S. (2013). Texte zur Theorie des Raums (RUB; 18953). Reclam.

Huber, C. (2018). Die Geschichte der Gegenwart Europas. Didaktisch-methodische Überlegungen. Praxis Geschichte, 3, pp. 10-11.

Kramper, P. (2009). Warum Europa? Konturen einer globalgeschichtlichen Forschungskontroverse. NPL, 54, pp. 9-46. https://doi.org/10.3726/91480_9

Knopke, L. (2011). Schulbücher als Herrschaftssicherungsinstrumente der SED. VS Research. https://doi.org/10.1007/978-3-531-93371-9

Lilla, M. (2018). Der Glanz der Vergangenheit. Über den Geist der Reaktion [The Shipwrecked Mind. On Political Reaction]. Neue Zürcher Zeitung.

Mishra, P. (2017, November 10). How colonial violence came home: the ugly truth of the first world war. The Guardian. https://www.theguardian.com

Mishra, P. (2018). Aus den Ruinen des Empires. Die Revolte gegen den Westen und der Wieder aufstieg Asiens [From the Ruins of Empire: The Revolt Against the West and the Remaking of Asia]. Fischer.

Moreno-Vera, J. R. \& Alvén, F. (2020). Concepts for Historical and geographical Thinking in Sweden's and Spain's Primary Education curricula. Humanities \& Social Sciences Communications, 7(7), pp. 1-10. https://doi.org/10.1057/ s41599-020-00601-z

Moreno-Vera, J. R. \& Martínez-Llorca, F. J. (2020). La narrativa del colonizador: la America Precolombina, un contenido 'invisible' en los libros de texto españoles. Izquierdas, 49, pp. 341-351. https://doi.org/10.4067/S071850492020000100220

Morris, I. (2012). Wer regiert die Welt? Warum Zivilisationen herrschen oder beherrscht werden. Campus.

Osterhammel, J. (2020). Rev. J. C. Sharman, Empires of the Weak. The Real Story of European Expansion and the Creation of the New World Order. Neue Politische Literatur, 65, 302-304. https://doi.org/10.1007/s42520-020-00215-4

Oswalt, V. (2019). Karten als Quelle und Darstellung. Historische Karten und Geschichtskarten im Unterricht (Forum historisches Lernen. Wochenschau. 
Popp, S. (2007). Europaweit gemeinsame Bilder? Anmerkungen zu europaweiten Präferenzen im Bildinventar aktueller Schulbüche. In B. Schönemann \& H. Voit, Europa in historisch-didaktischen Perspektiven (Schriften zur Geschichtsdidaktik; Vol. 22) (pp. 210-234). Schulz-Kirchner Verlag.

Popp, S. (2018). Zugriffsmöglichkeiten globalgeschichtlicher Perspektiven. In Globalgeschichtliche Perspektiven und Globales Lernen im Geschichtsunterricht. Konzeptionelle Überlegungen zur Unterrichtsmaterialienreihe "Wissen um globale Verflechtungen" (Wissen um globale Verflechtungen) (pp. 15-18). Center for InterAmerican Studies.

Rau, S. (2013). Räume. Konzepte, Wahrnehmungen, Nutzungen (Historische Einführungen; vol. 14). Campus.

Rehberg, K. (1994). Institutionen als symbolische Ordnungen. Leitfragen und Grundkategorien zur Theorie und Analyse institutioneller Mechanismen. In Die Eigenart der Institutionen. Zum Profil politischer Institutionentheorie (pp. 4784). Nomos.

Reinhard, W. (2008). Kleine Geschichte des Kolonialismus. Kröner Verlag.

Reinhard, W. (2016). Die Unterwerfung der Welt. Globalgeschichte der europäischen Expansion 1415-2015. C. H. Beck. https://doi.org/10.17104/9783406687198

Sabido-Codina, J. \& Albert Tarragona, J. M. (2020). Simultaneidad histórica y tratamiento didáctico del Holocausto. Cuestiones Pedagógicas, 29(1), pp. 3748. https://doi.org/10.12795/CP.2020.i29.03

Sáiz Serrano, J. (2014). Fuentes históricas y libros de texto en Secundaria: una oportunidad perdida para enseñar competencias de pensamiento histórico. ensayos, Revista de La Facultad de Educación de Albacete, 29(1), pp. 83-100. https://doi.org/10.18239/ensayos.v29i1.503

Schmid, H. (2009). Vom publizistischen Kampfbegriff zum Forschungskonzept. Zur Historisierung der Kategorie "Geschichtspolitik». In H. Schmid (ed.), Geschichtspolitik und kollektives Gedächtnis. Erinnerungskulturen in Theorie und Praxis (Formen der Erinnerung, vol. 41) (pp. 53-75). V\&R Unipress.

Schreiber, W. (2007). Einführung. In B. Schönemann \& H. Voit, Europa in historischdidaktischen Perspektiven (Schriften zur Geschichtsdidaktik; Vol. 22), (pp. 261263). Schulz-Kirchner Verlag. 
Thies, C. (2007). Arnold Gehlen zur Einführung. Junius.

Valls, R. (2009). Segunda República, Guerra Civil y dictadura franquista en las aulas (1938-2008). PUV.

Vallas, R., Parra, D., \& Fuertes, C. (2017). Los temas históricos conflictivos y su abordaje escolar: un ejemplo español. Clío \& Asociados. La historia enseñada, 25, pp. 8-21. https://doi.org/10.14409/cya.v0i25.6917

Viñao, A. (2014). From dictatorship to democracy: history of education in Spain. Paedagogica Historica, 50(6), pp. 830-843. https://doi.org/10.1080/0030923 0.2014 .948006

Von Borries, B. (2007). Europa als geschichtsdidaktische Herausforderung. In B. Schöemann \& H. Voit, Europa in historisch-didaktischen Perspektiven (Schriften zur Geschichtsdidaktik; Vol. 22) (pp. 21-44). Schulz-Kirchner Verlag.

Von Borries, B. (2008). Historisch Denken Lernen - Welterschließung statt Epochenüberblick. Geschichte als Unterrichtsfach und Bildungsaufgabe (Studien zur Bildungsforschung; vol. 21). Budrich. https://doi.org/10.2307/j.ctvbkk47b

Weidner, S. (2018). Jenseits des Westens. Für ein neues kosmopolitisches Denken. Hanser.

Wolfrum, E. (1999). Geschichtspolitik in der Bundesrepublik Deutschland. Der Weg zur bundesrepublikanischen Erinnerung 1948-1990. WBG.

\section{TEXTBOOKS THAT WERE CONSULTED}

German textbooks: Geschichte. Lehrbuch für Klasse 7, published in 1976; Fragen an die Geschichte 2. Die europäische Christenheit, published in 1981; bsv Geschichte 2. Vom frühen Mittelalter bis zum Westfälischen Frieden (bsv Geschichte in vier Bänden. Band 2 für die 8. Jahrgangsstufe der Gymnasien), published in 1983; Geschichte 7. Lehrbuch für Klasse 7, published in 1989; Geschichte kennen und verstehen 7, published in 2001; Geschichte und Geschehen 7, published in 2004; Horizonte 7. Geschichte Gymnasium Bayern, published in 2005; Das waren Zeiten 2. Mittelalter - Renaissance - Absolutismus, published in 2005; Forum Geschichte. Ausgabe Bayern. Band 2: Vom Mittelalter bis zum Absolutismus, published in 2005; \& Geschichte und Geschehen 7, published in 2019. 
Spanish textbooks: Historia Universal y de España, published by SM in 1965; Ciencias Sociales 70 EGB, published by Anaya in 1974; Bóveda Ciencias Sociales 70 EGB published by Anaya in 1983; Ciencias Sociales, Geografía e Historia 20 Ciclo, published by Anaya in 1999; \& Historia 20 ESO, published by Santilla in 2016. 